\title{
GENDER OF INTERNAL MEDICINE RESIDENT IMPACTS CANCER PREVENTION CARE FOR WOMEN
}

Maria Salguero ${ }^{1,2}$, Karen Cutts ${ }^{1}$, Saif Subhy Hamed Al Humaish ${ }^{3}$, Shyanne Page-Hefley ${ }^{1}$, Roger Smalligan ${ }^{4}$, Tetyana L. Vasylyeva ${ }^{1 *}$

Author information: ${ }^{1}$ Texas Tech University Health Sciences Center, $1400 \mathrm{~S}$ Coulter, Amarillo, TX, USA, ${ }^{2}$ Beth Israel Deaconess Medical Center, 330 Brookline Ave, Boston, MA, USA, ${ }^{3}$ Iraqi Board for Medical Specializations, Baghdad, Iraq, ${ }^{4}$ University of Alabama at Birmingham School of Medicine, 1270 2nd Ave, Huntsville, AL, USA

\begin{abstract}
Mammography and cervical screening are effective methods for early cancer detection in women. Recent reports showed that $69 \%$ of women $\geq 45$ years had a mammogram in the past 2 years and $16-55 \%$ of women had a Pap smear regularly. Internal medicine (IM) physicians are crucial players in women's health management and literature has identified that a physician's gender impacts patient management in many areas of healthcare. We investigated mammogram and Pap smear recommendations by IM residents and examined differences in approaching women's health issues between female and male residents. With IRB approval, one-hundred charts of new female patients were reviewed, which included female patients $\geq 45$ years seen by IM residents for their first visit. All patients completed a questionnaire concerning previous medical conditions and care as part of clinic routine. Patient chart information, recommendations for mammogram and cervical cancer screening by the resident were recorded, along with the gender of the resident and supervising attending. The mean age of the patients was $61 \pm 9.3$ years. Female residents were more likely to recommend a mammogram compared to male residents ( $36.7 \%$ and $16.4 \%$, respectively). No significant differences in Pap smear recommendations were observed between female and male residents $(9.3 \%$ and $10.1 \%$, respectively). Attending physician's gender did not influence screening recommendations. The recommendation rate for female patients to obtain important screening mammograms and Pap smears was low. These results are consistent with previous literature and indicate an urgent need for improved women's health education in residency, with special attention to male residents.
\end{abstract}

\section{Keywords: Cancer prevention, Breast cancer, Cervical Cancer, Primary Care, Gender Disparity}

INTRODUCTION Women's health is a public health priority and historically has been insufficiently emphasized in medical education and in the medical literature [1-3]. Many believe medical education in women's health is not adequate, and several national organizations have called for increased training ${ }^{3-5}$. IM physicians play a significant role in the management of women's health issues in the United States. Several studies have investigated IM residents' preparedness to care for women and have found that they're less prepared

*Corresponding author: Tetyana L. Vasylyeva, Texas Tech University Health Sciences Center, 1400 S Coulter, Amarillo, TX, USA, Tetyana.vasylyeva@ttuhsc.edu

Maria Salguero, Karen Cutts, Saif Subhy Hamed Al Humaish, Shyanne Page-Hefley, Roger Smalligan, Tetyana L. Vasylyeva () than family medicine and obstetrics-gynecology residents [6-2].

Schieber et al found differences in the management of patients based on the physician's gender in areas linked to women's preventive health [13]. Similarly, other studies have shown that a physician's gender can affect the rates of referral for proper women's cancer screening, including mammography and Pap smears [14-16]. This study was designed to determine a) the rate at which IM residents at a single university-based primary care clinic recommended preventive cancer screening tests to new female patients; b) if there was any difference in the approach to women's health issues by female and male residents and c) if there was any difference in approach based on the gender of the attending physician supervising the care of each patient. 


\section{MATERIAL AND METHODS}

Design A retrospective chart review of 100 consecutive, new female patients age 45 or above seen for their first annual health care visit between 2012 and 2015. The patients were seen by IM residents in the university resident clinic. Institutional Board Review approval for this study was obtained prior to beginning the chart review. The gender of the IM resident who had seen the patient, the patients' demographic characteristics, smoking habits, alcohol consumption, last Pap smear, last mammogram, whether they received annual check-ups, and recommendations for a mammogram and cervical cancer screening by the resident physician at their first visit were all extracted from the medical records and recorded. The gender of the attending physician supervising the resident was also noted
However, although no differences were found in rate of mammogram questionnaires completed, patients seen by a female resident were more likely to be recommended to get a mammogram (female IM resident: $36.7 \%$ vs. male IM resident: $16.4 \%, p=0.038$ ). Additionally, among the patients recommended to get a mammogram, action was taken more often when a female IM resident had made the recommendation (6/11 [54\%] vs. $3 / 10$ [30\%]).

Pap smear questionnaires completed, recommendations, and actions taken did not show differences between patient groups based on IM residents' gender (Table 1).

Male attending physicians acted as preceptors for the large majority of these first-time visits (80) compared with female preceptors (20). As shown in Table 2, no

\begin{tabular}{|c|c|c|c|}
\hline & $\begin{array}{c}\text { Female Resident } \\
(\mathrm{n}=32)\end{array}$ & $\begin{array}{c}\text { Male Resident } \\
(\mathrm{n}=68)\end{array}$ & p-value \\
\hline Age at visit (years), mean (SD) & $62.4(9.3)$ & $60.2(9.4)$ & 0.262 \\
\hline Mammogram & & & \\
\hline Questionnaire, $\mathrm{n}(\%)$ & $6(18.8)$ & $22(32.4)$ & 0.232 \\
\hline Recommended, $\mathrm{n}(\%)$ & $11(36.7)$ & $10(16.4)$ & 0.038 \\
\hline Action taken, $\mathrm{n}(\%)$ & $6(18.8)$ & $3(4.4)$ & 0.028 \\
\hline Pap smear & & & \\
\hline Questionnaire, $\mathrm{n}(\%)$ & $13(40.6)$ & $27(39.7)$ & 1.000 \\
\hline Recommended, $\mathbf{n}(\%)$ & $\mathbf{3 ( 9 . 4 )}$ & $\mathbf{7 ( 1 0 . 3 )}$ & $\mathbf{1 . 0 0 0}$ \\
\hline Action taken, $\mathbf{n}(\%)$ & $\mathbf{9 ( 2 8 . 1 )}$ & $\mathbf{1 9 ( 2 7 . 9 )}$ & $\mathbf{1 . 0 0 0}$ \\
\hline
\end{tabular}

Table 1. Difference in Recommendations by IM Residents

Statistical analysis Age was assessed using mean and standard deviation and other categorical variables were summarized using frequency and percentage. The statistical analyses assessed the differences based both on IM resident's gender and attending's gender. After checking distributional assumptions, differences between groups in continuous variables were tested using Student's t-test for independent means. Categorical variables were compared using chi-squared $\left(\chi^{2}\right)$ when cell frequencies were larger than 5 or Fisher's exact test otherwise. Significance level was set at 0.05 .

RESULTS The mean age of our patients was 61-years. Of the 100 patients, 68 were seen by male residents and 32 by female residents. When broken down by IM residents' gender, patient groups did not show differences in age. statistically significant differences were found when comparing the same parameters.

DISCUSSION The results of this study reflect a concerning low rate of attention to cancer screening in new female patients by this group of IM residents. Sadly, our findings are consistent with other studies that addressed IM resident's overall preparedness to provide women's health [5-6]. Multiple professional societies, including the American Board of Internal Medicine [3.9], the American College of Physicians, and the Federated Council for Internal Medicine, have all called for the inclusion of women's health topics more systematically in the IM resident training curriculum [10-11]. Despite these national recommendations, consistent implementation of women's health education into the curriculum remains a 


\begin{tabular}{|l|l|l|l|}
\hline & $\begin{array}{l}\text { Female Attending } \\
(\mathrm{n}=20)\end{array}$ & $\begin{array}{l}\text { Male Attending } \\
(\mathrm{n}=80)\end{array}$ & p-value \\
\hline Age at visit (years), mean (SD) & $62.4(9.3)$ & $60.2(9.4)$ & 0.750 \\
\hline Mammogram & & & \\
\hline Questionnaire, $\mathrm{n}(\%)$ & $7(35)$ & $21(26.2)$ & 0.436 \\
\hline Recommended, $\mathrm{n}(\%)$ & $6(31.6)$ & $15(20.8)$ & 0.323 \\
\hline Action taken, $\mathrm{n}(\%)$ & $3(15)$ & $6(7.5)$ & 0.378 \\
\hline Pap smear & & & \\
\hline Questionnaire, $\mathrm{n}(\%)$ & $9(45)$ & $31(38.8)$ & 0.610 \\
\hline Recommended, $\mathrm{n}(\%)$ & $2(10)$ & $8(10)$ & 1.000 \\
\hline Action taken, $\mathrm{n}(\%)$ & $6(30)$ & $22(27.5)$ & 0.824 \\
\hline
\end{tabular}

Table 2. Differences in Recommendations by Attending Physicians Supervising IM Residents

work in progress for most IM residency programs. Previous cross-sectional surveys of primary care program directors demonstrated some limited growth of women's health education opportunities in recent decades, with $52 \%$ of programs offering an elective ambulatory gynecology rotation in 1994 and $95 \%$ of programs offering a similar rotation in 2004. Resident utilization of these opportunities as a percentage remained constant with 68\% participating in 1994 and 67\% participating in 2004 $[5,6]$.

Compared to previous studies which showed that the gender of the IM resident could affect how women's health care is addressed, our findings were mixed. Female residents indeed recommended mammograms more frequently than their male counterparts and the patients were more likely to follow the female resident's advice. No such difference was seen with regard to the recommendation of Pap smears; however, the overall rate of appropriate Pap smear counseling was extremely low (10\% range).

Limitations to this study include the relatively small sample size, the male predominance in both the resident and faculty preceptor groups, and the fact that this was a single institution study. It should also be noted that data was collected from only the first patient visit and not the subsequent visits. New patient visits to an IM physician, especially when the average age of the patients is 60 years, is often a fairly complex and lengthy endeavor due to the number of chronic medical conditions that must be addressed. It may be that some of these residents planned to address the preventive medicine issues at a subsequent visit due to time constraints. Studies which have compared Family Medicine and OB-GYN preventive measures have generally resulted in better performance.

CONCLUSION This study further confirms the reports and recommendations of others demonstrating the urgent need for more emphasis on women's health issues during IM residency training. Program directors of residency training programs are urged to heed the call by the important national groups including the American Board of Internal Medicine, the American College of Physicians and the Federated Council for Internal Medicine to implement a more extensive and consistent women's health curriculum for IM residency programs across the nation [9-11].

ACKNOWLEDGMENTS: This study was supported in part by the TTUHSC Clinical Research Institute and TTUHSC Clinical Research Unit.

\section{REFERENCES:}

1. Healthy People 2010. Available at: http://www.healthypeople.gov. Accessed September 4, 2007.

2. Donoghue GD. Women's health in the curriculum: Resource guide for faculty: Undergraduate, residency, and continuing education, 1st ed. Philadelphia, PA: National Academy on Women's Health Medical Education (NAWHME), 1996.

3. Cassel C, Blank L, Braunstein G, Burke W, Fryhofer SA, Pinn V. What internists need to know: Core competencies in women's health. ABIM subcommittee on clinical competence in women's health. Am J Med 1997; 102:507-512.

4. Magrane D, Ephgrave K, Jacobs MB, Rusch R. Weaving women's health across clinical clerkships. Acad Med. 2000;75(11):1066-1070. 
5. Staropoli CA, Moulton AW, Cyr MG. Primary care internal medicine training and women's health. J Gen Intern Med. 1997;12(2):129-131.

6. Spagnoletti CL, Rubio DM, McNeil MA. Internal medicine residents' preparedness to care for reproductive-age and pregnant women. Teach Learn Med. 2007;19(3):257-263.

7. Kwolek DS, Witzke D, Sloan DA. Assessing the need for faculty development in women's health among internal medicine and family practice teaching faculty. The Women's Health Education Working Group (WHEWG). J Womens Health Gend Based Med. 1999;8(9):1195-1201.

8. Emmons S, Sells CW, Eiff MP. A review of medical and allied health learners' satisfaction with their training in women's health. Am J Obstet Gynecol. 2002;186(6):1259-1267.

9. American Board of Internal Medicine: Internal medicine certification examination blueprint. Available at: $\quad$ www.abim.org/exam/certification/internalmedicine.aspx (updated 2015).

10.American College of Physicians: ACP board prep curriculum: Women's health. Available at: www.acponline.org/education_recertification/educati on/boardprepcurriculum/slides/menu.html (updated 2014).

11. American college of physicians, federated council for internal medicine (FCIM): Graduate education in internal medicine: Resource guide to curriculum development. Available at: www.acponline.org/education_recertification/ education/training/fcim (updated 2002).

12. Spencer AL, Kern LM. Primary care program directors' perceptions of women's health education: A gap in graduate medical education persists. J Womens Health (Larchmt) 2008; 17:549-556.

13.Schieber AC, Delpierre C, Lepage B, Afrite A, Pascal J, Cases $C$, et al. Do gender differences affect the doctorpatient interaction during consultations in general practice? Results from the INTERMEDE study. Fam Pract. 2014 Dec;31(6):706-13. doi: 10.1093/fampra/cmu057. Epub 2014 Sep 11.

14. Lurie N, Slater J, McGovern P, Ekstrum J, Quam L, Margolis K. Preventive care for women. Does the sex of the physician matter? N Engl J Med. 1993 Aug 12;329(7):478-82.

15.Andersen MR, Urban N. Physician gender and screening: do patient differences account for differences in mammography use? Women Health. 1997;26(1):29-39.
16.Brooks DJ. Differences in Patient Screening Mammography Rates Associated With Internist Gender and Level of Training and Change Following the 2009 U.S. Preventive Services Task Force Guidelines. J Natl Compr Canc Netw. 2016 Jun;14(6):749-53.

17.Al-Obaide MAI, Ibrahim BA, Al-Humaish S, Abdel-Salam AG. Genomic and Bioinformatics Approaches for Analysis of Genes Associated With Cancer Risks Following Exposure to Tobacco Smoking. Front Public Health. 2018 Mar 20;6:84. doi: 10.3389/fpubh.2018.00084.

18. Naif HM1, Al-Obaide MAI2, Hassani HH3, Hamdan AS4, Kalaf ZS. Association of Cytochrome CYP1A1 Gene Polymorphisms and Tobacco Smoking With the Risk of Breast Cancer in Women From Iraq. Front Public Health. 2018 Apr 11;6:96. doi: 10.3389/fpubh.2018.00096.

19. Dossus L1, Boutron-Ruault MC, Kaaks R, Gram IT, Vilier $A$, Fervers $B$, et al. Active and passive cigarette smoking and breast cancer risk: results from the EPIC cohort. Int J Cancer. 2014 Apr 15;134(8):1871-88. doi: 10.1002/ijc.28508. Epub 2014 Jan 13.

20. Macacu A, Autier P, Boniol M, Boyle P. Active and passive smoking and risk of breast cancer: a metaanalysis. Breast Cancer Res Treat. 2015 Nov;154(2):213-24. doi: 10.1007/s10549-015-3628-4.

21.Roura E1, Castellsagué X, Pawlita M, Travier N, Waterboer T, Margall N, et al. Smoking as a major risk factor for cervical cancer and pre-cancer: results from the EPIC cohort Int J Cancer. 2014 Jul 15;135(2):453-66. doi: 10.1002/ijc.28666.

22. Goodman MT, Shvetsov YB, McDuffie K, Wilkens LR, Zhu $X$, Thompson PJ, et al. Prevalence, acquisition, and clearance of cervical human papillomavirus infection among women with normal cytology: Hawaii Human Papillomavirus Cohort Study. Cancer Res. 2008 Nov 1;68(21):8813-24. doi: 10.1158/0008-5472.CAN-081380.

23.Fanelli SL, Maciel ME, Díaz Gómez MI, Delgado de Layño AM, Bietto FM, et al. Further studies on the potential contribution of acetaldehyde accumulation and oxidative stress in rat mammary tissue in the alcohol drinking promotion of breast cancer. J Appl Toxicol. 2011 Jan;31(1):11-9. doi: 10.1002/jat.1555.

24. Castro GD, de Castro CR, Maciel ME, Fanelli SL, de Ferreyra EC, Gómez MI, et al. Ethanol-induced oxidative stress and acetaldehyde formation in rat mammary tissue: potential factors involved in alcohol drinking promotion of breast cancer. Toxicology. 2006 Feb 15;219(1-3):208-19. Epub 2005 Dec 27. 
25.Widschwendter P, Friedl TW, Schwentner L, DeGregorio N, Jaeger B, Schramm A. et al. The influence of obesity on survival in early, high-risk breast cancer: results from the randomized SUCCESS A trial. Breast Cancer Res. 2015 Sep 18;17:129. doi: 10.1186/s13058-015-0639-3.

26.Pajares B, Pollán M, Martín M, Mackey JR, Lluch A, Gavila J, et al. Obesity and survival in operable breast cancer patients treated with adjuvant anthracyclines and taxanes according to pathological subtypes: a pooled analysis. Breast Cancer Res. 2013 Nov 6;15(6):R105. doi: 10.1186/bcr3572.

27.Schlumbrecht MP, Sun CC, Huang MS, Zandstra F, Bodurka DC. Lifestyle modification in cervical cancer survivors: an ongoing need. Int J Gynecol Cancer. 2014 Mar;24(3):570-5. doi: 10.1097/IGC.0000000000000081.

28. Rottenberg Y, Naeim A, Uziely B, Peretz T, Jacobs JM. Breast cancer among older women: The influence of age and cancer stage on survival. Arch Gerontol Geriatr. 2018 May - Jun;76:60-64. doi: 10.1016/j.archger.2018.02.004.

29. Kohler BA, Sherman RL, Howlader N, Jemal A, Ryerson $A B$, Henry KA, et al. Annual Report to the Nation on the Status of Cancer, 1975-2011, Featuring Incidence of Breast Cancer Subtypes by Race/Ethnicity, Poverty, and State. J Natl Cancer Inst. 2015 Mar 30;107(6):djv048. doi: 10.1093/jnci/djv048. Print 2015 Jun.
30.United States Preventive Services Task Force. Screening for breast cancer: U.S. Preventive Services Task Force recommendation statement. Ann Intern Med 2009;151:716-726.

31.Elderkin-Thompson V, Waitzkin $H$. Differences in clinical communication by gender. J Gen Intern Med. 1999 Feb;14(2):112-21.

32. Henderson, Jillian T.; Weisman, Carol S. Physician Gender Effects on Preventive Screening and Counseling: An Analysis of Male and Female Patients' Health Care Experiences. Medical Care: December 2001 - Volume 39 - Issue 12 - p 1281-1292.

33. Mast MS, Hall JA, Köckner C, Choi E. Physician gender affects how physician nonverbal behavior is related to patient satisfaction. Med Care. 2008 Dec;46(12):12128. doi: 10.1097/MLR.0b013e31817e1877.

34.Dawn J. Brooks, MD, PhD. Differences in Patient Screening Mammography Rates Associated with Internist Gender and Level of Training and Change Following the 2009 U.S. Preventive Services Task Force Guidelines. Journal of the National Comprehensive Cancer Network 2016;14:749-753.

35. Hsieh E, Nunez-Smith M, Hendrich JB. Needs and priorities in women's health training: Perspectives from an internal medicine residency program. J Women's Health 2013;22:667-672. 